Canadian Journal of Higher Education Revue canadienne d'enseignement supérieur

Volume 43, No. 2, 2013, pages 68-84

\title{
Academic freedom in Canadian higher education: Universities, colleges, and institutes were not created equal
}

Barry E. Hogan

British Columbia Institute of Technology

Lane D. Trotter

Fanshawe College

\begin{abstract}
There has been substantial discussion, research, and debate about the role of academic freedom within higher education, primarily centered on the university model. Not as well documented or understood is the issue of academic freedom within colleges and institutes in Canada. In this paper, we examine the current state of academic freedom in colleges and institutes using a historical analysis of two Canadian provinces, British Columbia and Ontario. Beginning with an overview of academic freedom within universities, we then examine the development and evolution of colleges and institutes and discuss how or if academic freedom applies to them. We consider issues of collegiality, faculty engagement, and governance as they impact the concept and practice of academic freedom within these institutions. We also discuss the different origins, intents, roles, and governance models of universities in contrast to colleges and institutes, which are generally representative of the broader Canadian higher education landscape.
\end{abstract}

\section{Résumé}

Le rôle de la liberté universitaire dans l'enseignement supérieur a fait l'objet d'innombrables discussions, recherches et débats, la plupart axés sur le modèle universitaire. Pourtant, cette même notion est encore mal documentée et comprise dans l'enseignement dispensé par les collèges et instituts, surtout au Canada. Cet exposé examine l'état actuel de la liberté universitaire dans ces établissements, à l'aide d'une analyse historique et comparative de deux 
provinces canadiennes : la Colombie-Britannique et l'Ontario. Il commence par un survol de la liberté universitaire dans les universités, puis examine le développement et l'évolution de celle-ci dans les collèges et instituts et enfin, il se penche sur la façon dont on applique cette liberté, le cas échéant. Cet exposé traite également des questions de collégialité, de la participation des membres du corps professoral et de la gouvernance, selon leur incidence sur le concept et la pratique de la liberté universitaire. En outre, l'exposé discute des différents éléments que sont les origines, intentions, rôles et modèles de gouvernance d'universités, habituellement représentatives du paysage canadien de l'enseignement supérieur dans son ensemble, en les comparant aux collèges et instituts.

There has been a substantial body of discussion, debate, and research about the role of academic freedom within the university. That discussion has intensified, especially as it relates to the effects of globalization and academic capitalism on the university. What is not as well understood is academic freedom within colleges and institutes, particularly those within Canada. This is an important issue because Canadian colleges and institutes are different from their university counterparts and their role within the higher education landscape is changing. Colleges and institutes are now offering a limited number of bachelor's and master's degrees and engaging in applied research activities-the traditional domain of the university. This changing role has elevated the issue of academic freedom in colleges and institutes, particularly among faculty unions as it relates to workload, teaching assignments, and curriculum.

In this paper, we examine the current state of academic freedom in colleges and institutes through a comparative analysis of two provinces, British Columbia (BC) and Ontario. We begin with a brief review of academic freedom in the university context and then look at the application of academic freedom from a college and institute perspective. This analysis involves a historical review of colleges and institutes in BC and Colleges of Applied Arts and Technology (CAATs) in Ontario and takes into consideration the issues of collegiality, faculty engagement, and governance-concepts that are linked in varying degrees to academic freedom.

Prior to the 1960s, Canada had relatively few higher education institutions, most of which were universities. However, higher education expanded rapidly in the 1960 s in response to a growing economy and population, infrastructure development, increased immigration, the baby boom, and the shift in focus from an elitist system towards one of mass access (Buchbinder, 1993; Dennison \& Schuetze, 2004; Jones, 2004). This expansion relied in part on the unprecedented development of non-university components of higher education. These new institutions were called either community colleges or technical institutes and were designed to provide vocational training for graduates. Unlike universities, these new institutions were closely controlled by the government, were organized managerially, and directly aligned to meet the needs of the local community, business, and industry (Dennison \& Schuetze, 2004; Gallagher, 1995; Levin, 2001). Academic freedom was not an issue in the beginning because these new post-secondary institutions were not intended to be universities. The predominant structure of governance in Canadi- 
an universities can trace its origins back to the findings of the 1906 Flavelle Commission. That commission recognized the importance of faculty engagement in institutional governance and clearly articulated the rationale and framework for bicameralism-a model comprising two formally recognized bodies: a senior academic body, most often known as a senate, which operates in parallel to a board of governors (cited in Jones, Shanahan, \& Goyan, 2001). The University of Toronto became the first Canadian university to adopt this structure in 1906; Dalhousie, Queens, and McGill universities followed shortly afterwards, and the structure was eventually integrated into legislation in Western Canada (Horn, 1999; Jones, 1997). By the 1950s most Canadian universities had adopted the bicameral system (Jones, Shanahan, \& Goyan, 2004).

This paper examines academic freedom in colleges and institutes. A review of the existing literature indicates very little research has been conducted on academic freedom within Canadian colleges and institutes. Given the growth of the non-university post-secondary system, the issue of what academic freedom means within this sector will continue to become more important in the coming years. We initiate this discussion with a definitional understanding of academic freedom and what academic freedom means within the university sector. We will then apply this definition to the colleges and institutes and look at their evolution in BC and Ontario. We also examine the role that collegiality, faculty engagement, and governance have on academic freedom for colleges and institutes. Finally, we present our conclusion and discuss the implications of our findings for the future.

\section{Academic Freedom and Universities}

Universities have a history that predates the modern nation-state and can be traced back over 850 years to the founding of the University of Paris and the University of Bologna (Readings, 1996; Scott, 2006). A key function of the medieval university was to pursue divine truth-a function translated in the modern university into research, which is the foundation of academic freedom (Horn, 1999; Russell, 1993; Shils, 1991, 1993). In the university, academic freedom simply meant having the autonomy to pursue the truth regardless of where it led. Tenure was necessary in order to protect scholars whose findings were incompatible with accepted norms or truths from societal or institutional retribution in the form of job loss. As Horn (1999) indicates, "although imperfect, tenure seems to serve the needs of the universities and of society well enough. It may be necessary, though, to monitor it more carefully in order to ensure that those who enjoy its privileges continue to deserve them" (p. 308). This latter comment speaks to the need for appropriate self-governing and monitoring within the university so that faculty continue to control the academic agenda in accordance with a bicameral structure (Marginson, 2002).

While a majority of Canadian universities are publicly funded, they are legally considered private institutions. Even newer institutions created by the government have retained the rights, freedoms, and traditions of existing universities, including academic freedom (Mora, 2001). While there are different definitions of academic freedom, Horn's (1999) description of academic freedom within the Canadian university context can be summarized into five key elements: (a) the freedom to pursue truth wherever that may lead, (b) tenure so that the truth-seeker is not subject to loss of job when the research is controversial, (c) the ability of the scholar to be critical of the university, (d) the ability of the scholar to participate in public life, and (e) co-governance within the university. 
Horn (1999) indicates that these five elements are now generally accepted within the modern Canadian university. This acceptance raises the question whether there should be restrictions on academic freedom within the university. Tierney (1998) argues that academic freedom was more important in the past than in the present, noting the improved legal rights of faculty and a more enlightened climate than in the past. He adds that very few academics actually write or speak in a manner that requires the protection provided by academic freedom. Furthermore, as Horn (1999) indicates, academic freedom is not absolute:

Legitimate restrictions on academic freedom do exist. Academic freedom does not imply that the campus must be host to any and all behaviour short of the actually illegal. It does not justify defamation or the counselling of insurrection, or doing as little work as possible. Nor does it confer the liberty to teach whatever catches ones fancy. Course content may depend on the choices made by individual professors, but the subjects to be taught must be authorised by academic bodies. (p. 6)

A broader examination of the limitations of academic freedom reveals that while the scholar does have the right to pursue truth, they do not have the right to say or do anything. There is an active debate underway about the limits of academic freedom and this has been confused with issues of collective bargaining and faculty co-governance. One of the continuing debates within the university surrounds the requirement of scholars to adhere to course outlines. In universities, a course outline forms a contract between the students, the instructor, and institution; there is a both a moral and legal obligation for the scholar to follow the course outline. In examining academic freedom in U.S. higher education institutions, Fossey (2007) found the following:

Some college and university instructors apparently believe that they have a constitutional right to academic freedom that gives them license to do or say whatever they want in a college classroom. A review of court cases in this area shows that this attitude is wrong. Higher education institutions have a great deal of latitude in regulating their instructors' classroom teaching activities. (p. 159)

Fossey goes on to indicate that, in the United States,

[F]ederal courts have defined a college instructor's academic freedom rights narrowly in terms of the instructor's classroom activities. Institutions have a great deal of latitude to regulate an instructor's classroom speech, grading practices, and general manner of teaching a particular college-level course. (p. 159)

While academic freedom protects the right of the scholar to pursue truth through their research and teaching, institutions have the right to determine who can teach which courses, what may be taught in those courses, and who should be admitted into the university (Fossey, 2007; Shils, 1991).

One issue this raises is the balance between faculty decision-making rights and faculty responsibilities. Along with such decision-making rights come responsibilities (Hamilton, 2002; Shils, 1991). Academic freedom is premised on the expectation that the professoriate will self-regulate and participate in institutional governance. As Russell (1993) notes, unless faculty members exercise self-governance over the academic agenda, the ability to 
self-govern will be lost. Russell's concept of self-governance is very similar to MacIntyre's (1997) Aristotelian concept of practice:

[G]oods internal to that form of activity are realized in the course of trying to achieve those standards of excellence which are appropriate to, and partially definitive of, that form of activity, with the result that human powers to achieve excellence, and human conceptions of the ends and the goods involved are systematically extended. (p. 125)

Practice in this case refers to the faculty exercising appropriate self-governance and collegiality over its activities and members for the common good.

Hamilton (2002) suggests that faculty are generally unaware of the obligations associated with academic freedom and tenure. Tierney (1998) suggests that a faculty's professional responsibilities include obligations to one another, to the greater good of the institution, and to society. This position aligns with Shils' (1991) ideas on the constitution of academic freedom and the obligations thereby imposed on scholars:

The first obligation of an academic [is] to teach and to do research; each of these entail many subsidiary obligations. There are also obligations regarding conduct with pupils, with administrators, and with colleagues in academic institutions others than one's own. (p. 2)

Eckel (1999) also argues faculty must work with administrators in assuming the responsibility to make shared governance work. Braskamp and Wergin (1998) opine that academic freedom requires "freedom with responsibility, not freedom from responsibility" (p. 89).

In this section of the paper, we traced the origin of academic freedom to the medieval university and the pursuit of divine truth. We also demonstrated that academic freedom is tied to professional responsibilities within the university and the academic community. In the next section of the paper, we examine what academic freedom means within the context of colleges and institutes.

\section{The Evolution of Colleges and Institutes: A Historical Analysis}

Canadian colleges and institutes do not share a common history with Canadian universities or with universities in other countries. Provincial governments founded publicly funded community colleges and institutes to provide the education and training necessary to support economic development and competitiveness. Ontario, BC, and Alberta were the first provinces to legislate a community college system intended specifically to meet local or regional economic development needs (Fisher, Rubenson, Jones, \& Shanahan, 2009; Skolnik, 2010). Meanwhile, Quebec also enacted legislation creating the Collège d'Enseignement Général et Professionnel (CEGEP) program after Grade 11 with the dual purpose of both education and vocational training (Dennison, 1995a). Although the Ontario colleges were created with boards of governors, this was not the case with the other provinces. Rather, these colleges were originally controlled directly by their respective provincial governments until legislation was passed to give them a board governance structure. For instance, the last two major college systems to gain a measure of independence from their respective provincial governments were Nova Scotia Community College 
in 1996 and, more recently, New Brunswick Community College in 2010. However, in both circumstances, the colleges in Nova Scotia and New Brunswick were not given the bicameral governance structure, rights, responsibilities, and powers that exist for universities in those provinces. By not giving the colleges the same rights and responsibilities as universities, the provincial governments essentially created them to be different from universities.

The creation of colleges and institutes was an explicit attempt by provincial governments to produce a separate structure of higher education not intended to share the same historical rights and privileges as universities. Colleges and institutes were seen as a vehicle for technical education (techne) and not the Aristotelian education (episteme) offered in universities (Aristotle, trans. 2002). Considine (2006) explains the differences in purpose between universities and non-university institutions by indicating that "the key distinction was defined as the separation of knowledge creation and its later commercial application, or the difference between deep specialization and its subsequent synthetic forms in the professions and the workplace" (p. 257). Colleges and institutes were created as an explicit policy lever for economic development and were designed to be linked to industry. The legislation that created colleges in $\mathrm{BC}$ and Ontario was quite different than the legislation that existed for universities. Two of the major differences in the legislation were the governance structure and the ability of the minister to directly intervene in the affairs of the college-something the minister is forbidden to do with universities. In BC, the University Act (1996) specifies that the minister "must not interfere in the exercise of powers conferred on a university, its board, senate and other constituent bodies" (s. 48). In Ontario, the situation is slightly different since there is no single piece of legislation for universities, but rather an abundance of different legislation for each different university (Ontario, 1996). However, like in BC, none of this legislation provides a mechanism for the minister to directly intervene in the internal affairs of the universities. This is not the situation with the colleges and institutes where the minister does have the power to intervene.

We have established that when provincial governments created colleges and institutes, they were not provided with the same rights and responsibilities as universities. Academic freedom exists in universities because of the research conducted by faculty that expands the bounds of knowledge. Whether or not faculty in colleges and institutes have academic freedom remains to be determined. We will answer that question by looking at the evolution of colleges and institutes in two of the more mature jurisdictions of BC and Ontario where colleges and institutes have been given limited degree granting status and the authority to engage in applied research.

\section{British Columbia}

Narrowing the focus of this review to BC's higher education system reveals some noteworthy departures from the broader North American and Canadian patterns. Higher education was relatively late to develop in $\mathrm{BC}$, with the University of British Columbia (UBC)-which opened its doors to students in 1915-being the province's first university. UBC remained the province's sole university and one of only a few higher education options until the mid-196os (Dennison, 1992) when two events made a lasting impact. The first was the federal Technical Vocational Training Assistance Act (TVTAA) of 1960, which led to the rapid construction of new vocational training facilities across the country between 1960 and 1970 (cited in Dennison, 1992). The TVTAA led to new infrastructure 
being established across the province during the 1960s. The second key event in the development of BC's system of higher education was the report authored by UBC's president, John MacDonald, entitled "Higher Education in British Columbia" (1962). This report provided the foundation for two new universities and community colleges and was heralded as the single most influential event shaping BC's higher education system (Dennison, 1992). The 1980s brought a climate of fiscal restraint to BC and the College and Institute Act was amended creating government-appointed boards at each institution (cited in Dennison, 1992).

The 1990 s represented a key period of governance reform in higher education in BC. Historically, colleges and institutes had been governed more managerially than the relatively autonomous comprehensive universities (Cowin, 2007; Dennison \& Schuetze, 2004; Levin, 2001). However, the College and Institute Act (1996) was amended to establish education councils-whose members were representative, elected, and provided statutory authority over academic areas-as originally called for in the Duff and Berdahl (1966) report that was subsequently embraced by the Association of Universities and Colleges of Canada. This legislation ushered in a bicameral governance structure for BC colleges and institutes (Dennison, 1995a; Dennison \& Schuetze, 2004). Levin (2000) surveyed 104 community colleges across eight North American jurisdictions and concluded that, through specific legislation, only BC actually had the legal framework for shared governance in its colleges and institutes. It is important to understand that education councils do not have the full authority of university senates: the board of governors for colleges and institutes in $\mathrm{BC}$ retain both financial and academic responsibility, whereas university senates retain final authority for academic matters. While the creation of education councils moved $\mathrm{BC}$ colleges toward a co-governance model and provided faculty at the colleges and institutes with greater say over the academic core of programs and curriculum, it had little to no impact on academic freedom for the faculty within those institutions.

With the election of the BC provincial Liberal Party in 2001, BC's higher education system entered the $21^{\text {st }}$ Century with expectations for more dramatic change. The most significant indications of change were contained in the Campus 2020 report (Plant, 2007). This report was commissioned by the provincial government to provide a systemic approach to education reforms through to the year 2020, with the aim of making "BC the best educated, most literate jurisdiction in North America by 2015” (p. 3). It contained 52 sweeping recommendations impacting governance, accountability, funding, capacity, access, technology, participation, graduation objectives, student aid, scope of programs, private-sector participation, internationalization, research, credentials, and accreditation. Two years after the Campus 2020 report was released by the BC Ministry of Advanced Education and Labour Market Development (2009), five new universities were created out of three university colleges, one college, and one institute: Vancouver Island University, Kwantlen Polytechnic University, University of the Fraser Valley, Capilano University, and Emily Carr University of Art and Design. These five new universities now fall under BC's University Act (1996) and, despite their differences in background, traditions, culture, and conventions, have moved from education councils to senates with true academic decision-making powers and a bicameral structure. This poses interesting challenges for these new universities as they transition from a college culture to a university culture. One such challenge will be how they understand and implement academic free- 
dom in this new environment where the faculty will be expected to engage in research. It remains to be seen if the amount of research activity faculty engage in will be sufficient for these new universities to truly have or practice academic freedom.

It is clear that aside from these five new universities, the remaining colleges and institutes do not have the same rights as universities since the legislation for these institutions has not been changed. Although BC colleges and institutes are unique in having semiautonomous education councils, their primary focus still remains on teaching.

\section{Ontario}

The creation of the Ontario Colleges of Applied Arts and Technology (CAATs) in 1965 was a deliberate act by the government of Ontario to address the need for technical training outside the role of the university and beyond the level offered by the secondary school system. According to scholars such as Arvast (2008), Fisher et al. (2009), Jones (1991, 1997, 2004), and Skolnik (2010), the colleges have gone through a variety of transformative changes since their creation. These changes can be classified into four stages of evolution: (a) their initial creation and expansion in 1965 through to the early 1970s; (b) cost containment and controlled growth from the early 1970s to 1995; (c) the introduction of (neo-liberal) market mechanisms in 1995; and, finally, (d) the current stage from the early 2000 s to present, where the colleges were given limited ability to grant applied degrees and engage in applied research and innovation activities. Each of these stages is examined to look at what, if any, impact occurred to the issue of academic freedom within the college sector.

In the first stage, during a debate about the creation of a separate higher education system from the universities, the then Minister of Education, the Honourable William Davis, made a statement to the Ontario Legislative Assembly (1965) at Queen's Park that Ontario "must provide the facilities for education and training at these higher levels if we hope to continue to compete for markets on even terms at home and abroad" (p. 25). Mr. Davis elaborated that

[T] he need cannot be met simply by alterations or additions at secondary school level; this time we must turn our attention to the post-secondary level, where we must create a new kind of institution that will provide, in the interests of students for whom a university course is unsuitable, a type of training which universities are not designed to offer. (p. 27)

It is clear that the intention of the Ontario government was not to create a junior university or a college that would provide transfer to the universities-as was the case with the junior colleges in the United States-because there was a concern this would create confusion and conflict in the mission and mandate of the new colleges (Skolnik, 2010). The intent in creating the new college system was to create an educational structure with different rights and privileges than universities and a vocational focus designed to support the economic growth of the province (Jones, 1997). From the outset, Ontario colleges were created with a unicameral governance structure; each college had its own board of governors, as well as a central coordinating body, the Council of Regents. The Council of Regents was responsible for appointing external college lay-board members from the lo- 
cal community (Dennison, 1995a). This structure was designed to coordinate the growth of the college system and was successful given the rapid expansion achieved between 1965 and the early 1970 with the opening of 19 colleges (Jones, 1991, 1997), propelled initially by the federal TVTAA of 1960 (Skolnik, 2010).

By the early 1970s, the rapid expansion of the Ontario college system was slowed due to a severe recession, slow economic growth, and constrained government finances. This represented the start of the second stage in the evolution of Ontario colleges and was significant due to the deteriorating state of the labour-management relations within the colleges with several province-wide strikes during this period (Dennison, 1995a; Jones, 1997). The major issues that drove the strikes were related to workload and salaries. As an outcome, the government commissioned a series of reports that resulted in the creation of a province-wide workload formula and provided internal staff representation to each college's Board of Governors. While these changes were significant, the government did not act to implement a bicameral governance structure. Even when the New Democratic Party formed the provincial government between 1990 and 1995, they did not change the legislation to create a co-governance structure.

The third stage in the evolution of the colleges can be traced to the election of the Progressive Conservative Party in 1995. The progressive conservatives campaigned under a neoliberal platform called the "Common Sense Revolution." Once elected, they immediately moved to eliminate a large provincial deficit and create a more business friendly climate. Higher education was seen as a personal benefit rather than a social good, and cost-shifting marketization and privatization policies were introduced (Jones, 1997).

The fourth stage began in 2000 with the Post-Secondary Education Choice and Excellence Act passing into law. The new legislation allowed for the creation of private universities and for colleges to offer a limited number of applied degrees. This legislation marked a major change in the government's position about the binary divide in the roles and responsibilities between colleges and universities (Jones, 2004). Many colleges pursued the development of applied degrees and a small number of Ontario colleges also pursued a differentiated mission and mandate. Some of these institutions were re-designated as Institutes of Technology and Advanced Learning (ITALs) and, as Jones (2004) notes, "the new name is linked to the magnitude of applied degree programme activities at these institutions, it also signals a hierarchical differentiation between institutions in the CAAT sector" (p. 48).

One significant impact of both the Post-Secondary Education Choice and Excellence Act (2000) and the revised Ontario Colleges of Applied Arts and Technology Act (2002), which gave Ontario colleges limited degree-granting authority, was to raise the issue of academic freedom. The Colleges Academic Division (faculty component) of Ontario Public Service Employees Union (OPSEU) pursued academic freedom as part of the union settlement proposal during the collective bargaining round that occurred on August 31, 2009 (OPSEU, 2010). Although academic freedom was not included in that collective agreement, the issue of academic freedom was now a point of negotiation within the college sector. The issue of having academic freedom as part of the bargaining process is whether or not this becomes another avenue for entitlement. The real issue is whether teaching in and of itself constitutes the basis for academic freedom. Horn (1999), Russell (1993), and Shil $(1991,1993)$ would indicate that teaching without original research does 
not meet the criteria for academic freedom. At what point, if at all, does the current level of applied research conducted by the colleges tip the balance?

We have demonstrated that colleges and institutes-at least in two jurisdictions-occupy a unique role in post-secondary education. Even with the introduction of education councils, the focus of colleges and institutes has remained largely vocational. Allowing colleges and institutes limited degree-granting rights and the ability to engage in applied research represents a significant evolution in their mandate and function; however, the authority to engage in these activities is tightly regulated and limited. In the next section we will explore the implications of this evolution on academic freedom using Horn's (1999) five criteria, as well as considering issues of collegiality, faculty engagement, and governance.

\section{The Roles of Collegiality, Faculty Engagement, and Governance on Academic Freedom for Colleges and Institutes}

The changes that have occurred both inside and outside higher education institutions since the mid-1960s are significant. Rapid and sizeable expansion changed the nature of higher education and resulted in evolving approaches to institutional governance-essentially varying the degree to which power and decision-making was shared among faculty and stakeholders by the end of the 1970s. The 1990s saw the introduction of neoliberalism concepts such as privatization, marketization, and globalization, which exposed institutions to global information and comparisons, new markets for services and programs, new clients and, ultimately, both national and international competition. Government policies generally followed the neoliberal trend and encouraged academic institutions to expand their markets, their stakeholders, and their respective realms of entrepreneurial activity.

When compared to their mid-1960s counterparts, today's higher education institutions are generally much larger in size, more sophisticated, and often employ specialized administrators to satisfy their diverse stakeholders' expectations. Concurently, there has been a dramatic increase in the number of private higher education institutions offering a wide range of specialized programs (Fisher et al., 2009). The trend towards managerial models of governance may be consistent with neoliberal economics, but it represents a departure from the traditional collegial culture of governance in higher education (Codd, 2005; Harman \& Treadgold, 2007; Slaughter \& Leslie, 1997; Slaughter \& Rhoades, 2004). The Canadian Association of University Teachers (CAUT) has claimed that control of the universities remains with administrative groups, who operate universities without any accountability. Furthermore, the CAUT has claimed that in an attempt to increase efficiency, administrators have marginalized the roles of university senates in governance. In response, the CAUT recommended a shift in strategy and made collective bargaining its primary tool to protect and extend collegial governance models, as well as support the bicameral shared governance systems (CAUT, 2004). This position is contrary to the recommendations of the Duff and Berdahl (1966) commission that has been a defining feature of university bicameral governance in Canada for more than 45 years.

In colleges and institutes, collective agreements have provided similar protections to those offered by academic freedom - as identified by Horn (1999). While sharing similarities, the cultures found in universities and colleges or institutes are substantially different from one another and reflect a different history, evolution, and purpose-especially in terms of the faculty and administrators in these institutions. 
We will now look at how Horn's (1999) five elements of academic freedom relate to colleges and institutes. The earlier analysis showed the evolution of these institutions in both BC and Ontario, and we can use that analysis to examine the issue of academic freedom. With respect to Horn's first element, college and institute faculty members are primarily hired to teach and have broad discretion in how they teach as long as the objectives stated in the course outline are followed. This is the essential difference between college and institute faculty and university faculty-who are hired to do research and to teach. The second element-that of tenure-is addressed through seniority and job security provisions of the collective agreement that "provide faculty with a measure of economic security and protection from arbitrary dismissal" (Dennison, 2006, p. 117). The third condition of academic freedom Horn describes is the ability to be critical of the institution. Although some faculty at both universities and colleges may feel they cannot be critical of their institutions, their ability to do so is protected through collective agreements. The fourth element addresses the ability of the scholar to participate in public life. Faculty at both universities and colleges and institutes have the ability to participate in public life, although they may need to take a leave of absence if elected or appointed. The fifth and final condition of academic freedom, co-governance, is where the main difference exists between these different institutional types. Since the founding of the University of Paris, a tradition of legislated bicameral governance has existed in universities. We have shown that colleges and institutes do not share this history and were explicitly not given the same rights and privileges as universities. In $\mathrm{BC}$, the legislative change that created education councils was a strategic move by the government to provide a form of shared governance, giving faculty a greater voice over the academic affairs of the college or institute-although primary authority remained vested in the board. This is different in Ontario where the board has ultimate authority over both the financial and academic affairs of the college. Although structures such as academic or college councils exist, they are advisory to the president. Having said this, it is often at a president's peril not to be mindful of the advice provided.

We have demonstrated that many of the protections offered by academic freedom for faculty in universities have been achieved in the colleges and institutes through collective agreements. The two outstanding issues not covered by collective agreements relate to Horn's (1999) first and fifth elements of academic freedom: respectively, the pursuit of truth wherever that may lead and co-governance. Given the historic importance of the pursuit of the truth as the basis for academic freedom, we have shown that teaching by itself is not sufficient. The pursuit of truth is inexorably linked to pushing the boundaries of knowledge, and without that pursuit there cannot be any true academic freedom. In the case of co-governance, BC and Ontario have diverged. In BC, a semi co-governance structure was brought about by legislative change. This was not done in Ontario, and, consequently, it is clear that the provincial government does not intend for its colleges to mirror the governance structure of universities. We have also shown that these elements of academic freedom are now seen as bargaining positions for collective agreements. 


\section{Conclusion}

Over the past 40 years, higher education has undergone profound changes. Institutions that date back to the middle ages have experienced the most significant changes in their history and are now being challenged to reorganize their systems of governance and management (Mora, 2001). Some of these changes can be linked to massification; some to the lost monopoly on knowledge transmission. The creation of community colleges and institutes was an act of government designed to create a different type of higher education institution. Colleges and institutes were created to serve an economic function by providing skills and job training. Consequently, the governance structure of colleges and institutes was intended to be different. If colleges and institutes were designed to be the same as the universities, they would have had the same general governance structures as universities. These differences in structure have had major impacts on how the concept of academic freedom is understood and practiced at the respective institutional types.

The creation of colleges and institutes produced institutions that over time developed their own culture, conventions, and history whose primary focus from their creation was teaching, as differentiated from the research tradition of universities. The culture of colleges and institutes "emphasized teaching; [and] allowed for only an advisory role for faculty with respect to academic governance" (Dennison, 1995b, p. 135), whereas the culture of universities "emphasized research and scholarly activity; [and] practiced bicameral governance in which faculty members exercised considerable influence over academic affairs" (p. 135). The challenge colleges and institutes have faced since their founding has been maintaining a separate identity. This challenge has been exacerbated by the growth of the college and institute sector and the evolution of their mission and mandate-especially as they offer degrees and engage in applied research activities.

In $\mathrm{BC}$, some colleges have transformed from vocational training institutions to community colleges, university-colleges, and universities. For these new universities, the challenge will be to transition from the college tradition that emphasizes teaching to a new culture that emphasizes research and scholarly activity. With the universities, colleges, and institutes developing a greater overlap in their roles, the issue of academic freedom becomes increasingly unclear. These institutions were created at different historical times with very different objectives. The university has a long history, and within that history it has evolved and adapted around its core focus of pursuing truth through new knowledge (Readings, 1996; Scott, 2006). Conversely, colleges and institutes are very recent creations that have grown and become more sophisticated (Dennison, 1995a, 1995b), but are still primarily focused on career-based education linked to the labour market.

Considine (2006) points out that unless universities can maintain boundaries from other institutes and organisations, the autonomy and uniqueness of the university will be lost. Conversely, if colleges and institutes cannot maintain a clear vision of their roles, then they risk becoming a pale imitation of the university. There are increasing signals that the boundaries between colleges and universities are blurring (Jones, 2004). The challenge for colleges, institutes, and universities will be to maintain their unique identities while achieving a complimentary relationship with one another. If the universities are unable to maintain their unique identity, then they are in danger of losing their historic rights and privileges that formed the basis for academic freedom-rights that could easily 
be substituted with lesser ones such as bargained rights. Although this substitution might seem comparable, it is critical for the future of the universities that they maintain their historic autonomy from the state. As Russell (1993) indicates, "it is only in defending a medieval liberty, a sphere of academic freedom in which the state does not enter, that academic freedom in a Millite sense can be effectively defended" (p. 3). The implications for the colleges and institutes are just as significant. Although many colleges and institutes are now offering degree programs, their focus remains on vocational instruction. This focus fits within the original rubric of colleges and institutes as economic levers for their communities by providing skilled and trained graduates to meet the needs of employers.

The creation of the university and its subsequent evolution is different than the deliberate strategy used by government to create colleges and institutes. The internal structures of these institutions are very different from those in universities and have had an indelible impact on how academic freedom is understood and practiced at colleges and institutes in BC and Ontario. It is clear that the colleges and institutes are not universities. They are institutions created to meet the labour market needs of their communities and support economic development and competitiveness. They are nimble institutions capable of evolving to meet the changing needs of their communities by offering higherlevel credentials and engaging in applied research that better prepares students for the labour market. At some point this may change, but, at present, colleges and institutes remain teaching institutions. By maintaining a focus on meeting the needs of the labour market, colleges and institutes can ensure their unique identity. As long as their focus is clear, there will be complementarity with the universities. As teaching institutions, colleges and institutes will continue to have a different relationship than universities with academic freedom.

With mounting pressure for post-secondary institutions to evolve and innovate, the concept of academic freedom will continue to be re-evaluated, reinvented, and possibly even replaced in the coming years. The challenge for colleges and institutes is to recognize both their role as teaching institutions and the implications for academic freedom that come with that role.

\section{References}

Aristotle. (2002). Niccomachean Ethics (C. Rowe, Trans.; S. Broadie, Ed.). Oxford, England: Oxford University Press.

Arvast, A. (2008). The new CAAT: (Dis)illusions of freedom and the new college charter in Ontario. The Canadian Journal of Higher Education, 38(1), 105-121.

Braskamp, L. A., \& Wergin, J. F. (1998). Forming new social partnerships. In W. G. Tierney (Ed.), The responsive university: Restructuring for high performance (pp. 6291). Baltimore: John Hopkins University Press.

British Columbia Ministry of Advanced Education and Labour Market Development. (2009). Campus 2020: Thinking ahead. Retrieved June 7, 2009, from http://www.aved. gov.bc.ca/campus2020

Buchbinder, H. (1993). The market oriented university and the changing role of knowledge. Higher Education, 26(3), 331-347. 
Canadian Association of University Teachers (CAUT). (2004). CAUT policy on governance: Where we have been and where we should go. Ottawa, Ontario: Author.

Codd, J. (2005). Teachers as 'managed professionals' in the global education industry: The New Zealand experience. Educational Review, 57(2), 193.

College and Institute Act, R.S.B.C. 1996, c. 52. The Revised Statues and Consolidated Regulations of British Columbia [Electronic version]. Retrieved February 12, 2013, from http://www.bclaws.ca/EPLibraries/bclaws_new/document/ID/freeside/o0_96052_01

Considine, M. (2006). Theorizing the university as a cultural system: Distinctions, identities, emergencies. Educational Theory, 56(3), 255-270.

Cowin, B. (2007). Made in BC: A history of postsecondary education in British Columbia. Vancouver, British Columbia: Author.

Dennison, J. D. (1992). Higher education in British Columbia, 1945-1992: Opportunity and diversity. Vancouver, British Columbia: University of British Columbia Press.

Dennison, J. D. (1995a). Community college development in Canada since 1985. In J. D. Dennison (Ed.), Challenge and opportunity: Canada's community colleges at the crossroads (pp. 13-104). Vancouver, British Columbia: University of British Columbia Press.

Dennison, J. D. (1995b). Organization and function in postsecondary education. In J. D. Dennison (Ed.), Challenge and opportunity: Canada's community colleges at the crossroads (pp. 121-140). Vancouver, British Columbia: University of British Columbia Press.

Dennison, J. D. (2006). From community college to university: A personal commentary on the evolution of an institution. Canadian Journal of Higher Education, 36(2), 107124 .

Dennison, J. D., \& Schuetze, H. (2004). Extending access, choice, and the reign of the market: Higher education reforms in British Columbia, 1989-2004. The Canadian Journal of Higher Education, 34(3), 13-38.

Duff, J., \& Berdahl, R. (1966). University government in Canada: Report of a commission sponsored by the Canadian Association of University Teachers and the Association of Universities and Colleges Canada. Toronto, Ontario: University of Toronto Press.

Eckel, P. D. (1999, November). The role of shared governance in institutional hard decisions: Enabler or antagonist? Paper presented at the annual meeting of the Association for the Study of Higher Education, San Antonio, TX.

Fisher, D., Rubenson, K., Jones, G., \& Shanahan, T. (2009). The political economy of post-secondary education: A comparison of British Columbia, Ontario and Quebec. Higher Education 57(5), 549-566.

Fossey, R. (2007). University oversight of professors' teaching activities: A professor's academic freedom does not mean freedom from institutional regulation. Journal of Personnel Evaluation in Education 19(3-4), 159-173. 
Gallagher, P. (1995). Promise fulfilled, promise pending. In J. D. Dennison (Ed.), Challenge and opportunity: Canada's community colleges at the crossroads (pp. 256274). Vancouver, British Columbia: University of British Columbia Press.

Hamilton, N. (2002). Academic ethics: Problems and materials on professional conduct and shared governance. Westport, CT: Praeger.

Harman, K., \& Treadgold, E. (2007). Changing patterns of governance for Australian universities. Higher Education Research and Development, 26(1), 13-29.

Horn, M. (1999). Academic freedom in Canada: A history. Toronto, Ontario: University of Toronto Press.

Jones, G. A. (1991). Modest modification and structural stability: Higher education in Ontario. Higher Education, 21(4), 573-587.

Jones, G. A. (1997). Higher education in Ontario. In J. A. Jones (Ed.), Higher education in Canada: Different systems, different perspectives (pp. 137-159). New York: Garland Publishing.

Jones, G. A. (2004). Ontario higher education reform, 1995-2003: From modest modifications to policy reform. The Canadian Journal of Higher Education, 34(3), 39-54.

Jones, G. A., Shanahan, T., \& Goyan, P. (2001). University governance in Canadian higher education. Tertiary Education and Management, 7(2), 135-148.

Jones, G. A., Shanahan, T., \& Goyan, P. (2004). The academic senate and university governance in Canada. The Canadian Journal of Higher Education, 34(2), 35-68.

Levin, J. S. (2000). What's the impediment? Structural and legal constraints to shared governance in the community college. The Canadian Journal of Higher Education, $30(2), 87$.

Levin, J. S. (2001). Globalizing the community college. New York: Palgrave.

MacDonald, J. B. (1962). Higher education in British Columbia and a plan for the future. Vancouver, British Columbia: University of British Columbia Press.

MacIntyre, A. (1997). The nature of the virtues. In R. Crisp \& M. Slote (Eds.), Virtue ethics (pp. 118-140). Oxford, England: Oxford University Press.

Marginson, S. (2002). Nation-building universities in a global environment: The case of Australia. Higher Education, 43(3), 409-428.

Mora, J.G. (2001). Governance and management in the new university. Tertiary Education and Management, 7(2), 95-110.

Ontario Legislative Assembly. (1965, May 21). Hansard: Official report of debates. 27th Parliament, 3rd Session, 3185-3192.

Ontario Colleges of Applied Arts and Technology Act, R.S.O. 2002, c. 8. Revised Statutes and Consolidated Regulations of Ontario [Electronic version]. Retrieved February 12, 2013, from http://www.e-laws.gov.on.ca/html/statutes/english/elaws_ statutes_02008f_e.htm 
Ontario Public Service Employees Union (OPSEU). (2010, January 20). Union proposal for settlement [Electronic version]. Retrieved February 12, 2013, from http:// www.opseu.org/caat/caat_ac/2009Bargaining/pdf/Union\%20proposal\%20for\%20 settlement\%20-\%20Jan\%2020,2010.pdf

Plant, G. P. (2007). Campus 2020: Thinking ahead: The report. Victoria, British Columbia: Ministry of Advanced Education.

Post-secondary Education Choice and Excellence Act, 2000, R.S.O. c. 36. Revised Statutes and Consolidated Regulations of Ontario [Electronic version]. Retrieved February 12, 2013, from http://www.e-laws.gov.on.ca/html/statutes/english/elaws_ statutes_oop36_e.htm

Readings, B. (1996). The university in ruins. Cambridge, MA: Harvard University Press.

Russell, C. (1993). Academic freedom. London: Routledge.

Scott,J.(2006). The mission of the university: Medieval to postmodern transformations. Journal of Higher Education, 77(1), 1-39.

Shils, E. (1991). Academic freedom. In P.G. Altbach (Ed.), International higher education: An encyclopedia (pp. 1-22). New York: Garland Publishing.

Shils, E. (1993). Do we still need academic freedom? The American Scholar, 62(2), 187-209.

Skolnik, M. L. (2010). A look back at the decision on the transfer function at the founding of Ontario's colleges of applied arts and technology. Canadian Journal of Higher Education, 4O(2), 1-17.

Slaughter, S., \& Leslie, L. L. (1997). Academic capitalism. Baltimore: The John Hopkins University Press.

Slaughter, S., \& Rhoades, G. (2004). Academic capitalism and the new economy: Markets, state and higher education. Baltimore, MD: John Hopkins University Press.

Tierney, W. G. (1998). Tenure is dead: Long live tenure. In W. G. Tierney (Ed.), The responsive university: Restructuring for high performance (pp. 38-61). Baltimore: The John Hopkins Press.

University Act, R.S.B.C. 1996, c. 468. The Revised Statues and Consolidated Regulations of British Columbia [Electronic version]. Retrieved February 12, 2013, from http://www. bclaws.ca/EPLibraries/bclaws_new/document/ID/freeside/oo_96468_01

\section{Contact Information}

Barry Hogan

British Columbia Institute of Technology

3700 Willingdon Avenue

Burnaby, British Columbia, Canada, V5G 3H2

barry_hogan@bcit.ca 
Lane D. Trotter

Fanshawe College

1001 Fanshawe College Boulevard

P.O. Box 7005

London, Ontario, Canada, N5Y 5 R6

ltrotter@fanshawec.ca

Barry Hogan, Ed.D, is BCIT's Dean of Academic Planning and Quality Assurance. BCIT is among British Columbia's largest post-secondary education institutions (50,00o full and part-time students and 350 programs ranging from apprenticeship training to Master's degrees). In his current role, Barry leads all aspects of BCIT's programming quality and collaborates with stakeholders across the Institute, as well as externally with other postsecondary institutions and the Ministry of Advanced Education. Dr. Hogan holds a Doctorate in Educational Leadership (Ed.D.) from Simon Fraser University, an MBA from University of Toronto, and a Bachelor of Commerce from University of Windsor.

Lane Trotter, Ed.D., is the Senior Vice President Academic at Fanshawe College in London, Ontario. Fanshawe College is one of Ontario's largest Colleges with over 17,000 fulltime and 30,000 part-time learners. As Senior Vice President Academic, Dr. Trotter is responsible for providing the academic leadership, vision and direction for the College. Over the last three years, he has led the Strategic Enrolment Management (SEM) initiative to reposition the College to respond to a more fluid external environment. Dr. Trotter holds a doctorate in Educational Leadership (Ed.D.) from Simon Fraser University and a MPA and BA from the University of Victoria. 